\title{
SOCIAL AND HUMANISTIC FUNCTION OF INCLUSIVE EDUCATION
}

Malyshevska Iryna, Doctor of Pedagogical Sciences, Associate Professor of Special Education Department, Pavlo Tychyna Uman State Pedagogical University.

ORCID: 0000-0003-0889-2552

E-mail: irinamalysh66@gmail.com

Demchenko Iryna, Doctor of Pedagogical Sciences, Professor of Special Education Department, Pavlo Tychyna Uman State Pedagogical University.

ORCID: 0000-0003-4302-7564

E-mail: irynadi67@gmail.com

Chyrva Hanna, PhD in Pedagogical Sciences, Associate Professor of Special Education Department, Pavlo Tychyna Uman State Pedagogical University.

ORCID: 0000-0003-3791-6111

E-mail: ch56@i.ua

The article deals with historical and philosophical analysis of the social and humanistic function of inclusive education. Its origin comes out of the idea based on the principles of equality and availability. The paper determines that the leading strategy for the development of the modern education system is its reconstruction on a humanistic basis, formation of the alternative models of psychological and pedagogical support in the country and mechanisms for free forms of education of children with special educational needs choice in accordance with their educational needs. Hence, the philosophical discourse actively discusses concepts related to the implementation and dissemination of an inclusive model of education.

Keywords: inclusive education, inclusive philosophy, exclusion, segregation, integration, inclusion, children with special educational needs, social and humanistic function of inclusive education, humane society.

\section{СОЦАЛЬНО-ГУМАНІСТИЧНА ФУНКЦІЯ ІНКЛЮЗИВНОЇ ОСВІТИ}

Малишевська Ірина, доктор педагогічних наук, доцент кафедри спеціальної освіти, Уманський державний педагогічний університет імені Павла Тичини.

ORCID: 0000-0003-0889-2552

E-mail: irinamalysh66@gmail.com

Демченко Ірина, доктор педагогічних наук, професор кафедри спеціальної освіти, Уманський державний педагогічний університет імені Павла Тичини.

ORCID: 0000-0003-4302-7564

E-mail: irynadi67@gmail.com

Чирва Ганна, кандидат педагогічних наук, доцент кафедри спеціальної освіти, Уманський державний педагогічний університет імені Павла Тичини.

ORCID: 0000-0003-3791-6111

E-mail: ch56@i.ua 
У статті представлено історико-філософський аналіз сочіально-гуманістичної функиіі інклюзивної освіти, в основу якої покладена ідеологія, щьо базується на засадах рівноправності. Інклюзивні тендениії, щзо набирають обертів у сучасній освіті, резонують з демократичними процесами у суспільстві і створюють реальні умови доступності освіти для усіх $і$ розвитку загальної освіти з урахуванням різних особливостей психофізичного розвитку дітей.

Визначено, щуо провідною стратегією розвитку сучасної системи освіти є ї̈ реконструювання на гуманістичних засадах, створення в краӥні альтернативних моделей психолого-педагогічної підтримки та механізмів для вільного вибору форм навчання дітей з особливими освітніми потребами відповідно до їх освітніх потреб. У зв'язку з иим, у філософському дискурсі активно обговорюють конщепції, пов'язані з упровадженням та розповсюдженням інклюзивної моделі освіти.

Досліджено соціально-гуманістичні функиї інклюзивної освіти, які закладені в принципах інклюзї̈ $і$ лежать в основі нової моделі суб'єкт-суб'єктних відносин в освіті. Визначено дитиноцентристську ідеологію інклюзивної освіти, принципи і иінності якої базуються на визначенні значущості кожного суб 'єкта освітнього прочесу.

Сформулювано висновок, що інклюзивна освіта: феноменологічно пов'язана з розвитком інклюзивного суспільства, що підтверджує етапність іï розбудови: ексклюзія, сегрегаџія, інтеграція, інклюзія; довготривала перспектива, яка упродовж кількох поколінь покликана зламати ексклюзивні устої і сформувати нове цивілізоване, гуманне суспільство.

Для пошуку оптимальних иляхів розбудови інклюзивної освіти доцільним є створення інклюзивних освітніх середовищ у масових закладах освіти, спрямованих на успішну сочіалізацію дітей з особливими освітніми потребами.

Ключові слова: інклюзивна освіта, філософія інклюзї, ексклюзія, сегрегачія, інтеграція, інклюзія, діти з особливими освітніми потребами, соціально-гуманістична функція інклюзивної освіти, гуманістичне суспільство.

Today under the influence of humanistic requirements, native education is being reformed that is caused by social and economic, political, spiritual and cultural changes in the renewing society. In present education the idea that is connected with goal setting changes in the sphere, is being realized - starting with the knowledge formation to the competence formation, with "personality for the society" to "personality in the society". Education technology renovation, the arrangement and implementation process of personal educational services, that include the development of every child despite his state of health and social origin, are currently of great interest.

The situation of present education indicates that the implementation of humanistic, democratic basis has been started. That led to the following: any atypical forms (belonging to ethnic, language, cultural or religious minorities, endowments, mental specific features, disabilities etc.) are no more treated as a natural condition for different people coexistence; often it leads to social deprivation and isolation of the children who on any features differ from most of their peers. This humanistic function is implemented by inclusive education; on the point of world pedagogics, it is the most powerful innovative trend in education [1].

Theoretical results and practical experience of inclusive education realization and implementation are described in foreign and native scientific studies of J. Deppeler [4], V. Zasenko [3], A. Kolupaieva [1], T. Lorman [4], D. Harvey [4] and others. The analysis of their works proves the change of education philosophy in humanization and tolerance, the adoption of inclusion philosophy by all education participants. The inclusion is defined by person-centered idea and is based on the principles of equality, dignity and the difference of children groups involving.

The article deals with theoretical analysis of social and humanistic function of 
inclusive education based on the ideas of moral and social responsibility including available qualitative education for every child.

The renovation of civil society contributes to democratic values improvement. Thus, it is inclusive education that is a vital condition for every child being successful as adults, and has its clear values; they are the surface for inclusive education. It is specified by great potential of any educational and educative process that leads to comprehensive child development, its successful socialization, development of cognitive possibilities and valuable orientation. Social changes in valuable and moral norms modify methodological basis of education, create new perception of their relations.

Having adopted foreign experience and experimental data of native studies, we need to develop inclusion dealing with economical state, social processes, degree of democratic institutions' maturity, and relation to the children with special educational needs fixed in the society. Additionally, it is necessary to include existing complex programs of early (from the earliest months) psychological and pedagogical correction that helps to ascend many 'problem' children to the level of psychological and physical development to provide their earliest adaptation to general educational environment. Every child with special educational needs requires specific pedagogical help and psychological support.

It is completely urgent to inquire into the existence of two systems that have been developed separately for long time - special education based on traditional medical classifications, on the one hand, and mass education having conservative conception oriented on the successful uniform educational groups, on the other hand. In reality, the attempts to combine these two systems lead to considerable difficulties in inclusive education realization. Inclusive education is not able to substitute special education completely, as it broadens the opportunities of inclusive education. One should remember that it is inclusion that is characterized by flexible organization of educational process. It has the ability to give the appropriate form of education for the people who have appeared to live in difficult conditions with different difficult problems. In accordance with the fact, inclusive education reveals the social model having relied on the idea of inclusive society that builds new relations, tries to understand and contribute to social practice of children with special educational needs.

Today, in the time of current democratic changes in the country, the research of inclusive education problems requires the analysis of its philosophy and gnoseology, empiric experience of its development and implementation, the perception of its significance and importance like a social and humanistic paradigm.

In foreign pedagogy in the context of inclusion philosophy, ecological paradigm is being developed; here the main role is for child's social surrounding. In the context of the study, environment is described not only as a combination of separate factors, but as their systemic consolidation oriented on child's provision by favorable conditions for the development. In inclusive education ecological approach includes the orientation of whole pedagogical activity on the construction of comfortable life surrounding for a child with special educational needs. Accordingly, the problems of children with special educational needs are necessary to be studied in complex based on the systemic approach of the child's inclusion into the society, rather than separately.

According to the researches V. Zasenko and A. Kolupaieva, today society deals with the alternative attitude to the children with special educational needs: people recognize their 
right to be unique and respectful. Mostly it is shown in the idea of inclusion that considers natural skills, interests and abilities of the children with special educational needs. The researches highlight the idea of inclusive education showing that a child is an individual and unique personality and has his own interests, abilities and needs. Thus, he requires personal approach while studying, and flexible curricula including these specific features. Personal approach requires a teacher to be highly professional - he should be ethical, flexible, delicate, and ready to understand. Additionally, inclusive education forms its own scale of values (axiology) with the following principles: regardless of abilities, skills and achievements, every person performs the right to education, self-expression and personal progress [3].

Being a specific philosophy, inclusion satisfies needs in education, discovers and develops personal skills, supports and encourages self-confidence, promotes perfect adaptation, socialization, self-realization acquiring experience (communicative, social, psychological) of the children with special educational needs. Owing to inclusion one may notice isolation and alienation ascending of the child; he becomes more active, the feeling of being 'special' disappears. Diversity, dissimilarity of children appears to be powerful resource that helps them to develop and reveal their creative potential. Implementation of inclusive education promotes restructuring of educational establishment's culture, including everybody: teachers, children and their parents. That creates conditions for further demonstration and life of children with special educational needs in society. Generally, inclusive education is a unique process of available education for everybody.

'In a perfect variant, inclusion deals with complete integration of all pupils into every educational aspects and schools life. In other words, mass schools and classes need to be sensitive to the needs of every pupil; in order to satisfy them, they need to be ready to fit to the reality. Additionally, they should respect and appreciate the difference' [4]. Thus, social and educational conditions need to be oriented on the situation when a child with special educational needs is maximum independent and autonomous. Here the child has an active and responsible life position, is a partaker in society and is able to realize himself there. Today the concept of independent and autonomous way of life of children with special educational needs shows the approaches to form purposes and content of inclusive education.

Axiological positions of some present philosophical approaches help analyze the problems of valuable attitude to the inclusive education itself and the person with special educational needs in conditions of the education. The obtained results of the analysis can be used to solve ontological problems as following: the problem of genesis quality of a disabled person on the condition of existence and absence of inclusive studying. The character of these problems solving identify the specific features of social and philosophical accomplishment of the life and education particularly, socialization and survival of a person with special educational needs in modern world [5]. Today there is no universal methodology of inclusive education. Opportunities, purposes, content and meaning of inclusive education demands the extension, because different inclusion models are not able to satisfy all children's specific needs. According to T. Lorman: "Inclusion which depends on the context and the impression based on the work of a group of pupils is different to the experience of others". "... There is no "correct" way to involve every pupil; but... there is a general technology one may take into account and it may help achieve positive results" [4, p. 31]. The researches T. Lorman, J. Deppeler and D. Harvey say: "Not every attempt to implement inclusive model is 
successful". According to these data, some specialists encourage to refuse mass use of the practice and limit its target audience by the children whose needs are trivial. But the opinion is based on mistaken reasoning [4, p. 18]. The expulsion of children with special educational needs from the institutions of pre-school, general secondary education make one doubt the ability of present educational systems to provide effective education in democratic society.

The principals of inclusion find social and humanistic function of inclusive education. It also completes the base for new model of educational relations. These principals were formed twenty years ago and confirmed by the international Declaration [6]:

1. The values of a person do not depend on his abilities and achievements.

2. Every person is able to percept and think.

3. Every person performs the right to communicate and to be heard.

4. Everybody needs each other.

5. The true education can be performed in real relations only.

6. Everybody needs the support and friendship of the peers.

7. Diversity intensifies all sides of person's life.

Thus, inclusive education is a dynamically developed process. It is not a fact, event or index, but the development and change process of the policy, culture and educational practice based on the inclusion principals. inclusion:

The studying in educational establishments should follow the principals of educational

- every child is an individual personality with different educational needs;

- exclusion of any discrimination of children with special educational needs;

- educational establishments are open for every child regardless of their psychological and physical specific features;

- children should study all together despite of their specific developmental features;

- educational establishments recognize and appreciate all children's needs according to their abilities and the pace to absorb the material;

- the development of curricula and the teaching strategy (individual if necessary) oriented on providing qualitative education of children with special educational needs;

- children with special educational needs should be given psychological and pedagogical help of the specialist with different specializations.

These principals are equal to the principals of social inclusion. "Social inclusion (engagement, involving) has appeared as a result of society transfer to social policy based on the social model of disability. Actually, it is the process of changes in political, economic and social spheres oriented on social equality recognition. It means providing of the conditions when every child and adult may take part in the society life as its equal partners to be respected and contribute to its development. Social inclusion represents active and personaloriented approach and their aspiration for social wealth. It includes not only barriers or risks destruction, but the concept change of social policy". Thus, Victoria Government Department of Health and Human Services (Australia) identifies the basic principles of social inclusion: every child is ready to study, communicate, and is able to contribute; all together we are better [2, p. 96-97]. To conclude, inclusive education is child-centered and confirms every child to be an individual with different needs in education.

To make inclusive education effective, teaching and studying strategy should be 
accepted. If education is more effective because of inclusive innovations influence, every child advances, rather than children with special educational needs. Studying in inclusive educational establishments helps children with special educational needs obtain knowledge and social experience. It may reduce discrimination, as while studying to cooperate with one another, children learn to recognize and accept differences. It is vital to have been set since early childhood, because a disabled person does not differ in anything but in these possibilities.

Under these conditions, inclusive education may be a giant leap for children with special educational needs. They will start to extend toward the children with normal development and equal them. They will understand they are accepted, but pushed off; they are encouraged and supported; a personality but a disease is important. It will help them believe in their own possibilities.

Inclusion is an approach and philosophy that involves the fact every child (having both special needs and not) may receive more opportunities in social approach and education as well. Inclusion does not mean gathering all the children together, but, on the contrary, promoting every child to feel his skills and needs accepted and appreciated [7].

Thus, Finnish researcher S. Hakkinen says: "Inclusion is a process that comes through the whole society. We believe that a disabled person may be involved in society during the whole life, rather than a schooler or a preschooler; when the person works, has a rest and communicates as a society participant. It requires society to think and act in inclusive position. It is impossible to change society mentality immediately. First of all, inclusive education performs the teaching role of the new generation changes" [8].

Foreign experience analysis shows that inclusive education development is a longterm strategy. Its ideology, tolerance, sequence, phasing and complex approach need to be realized.

The analysis of historic and philosophical literature helps to determine the following features of social and humanistic function of inclusive education:

- inclusive education is a historical process of the transfer from exclusion, segregation (separation) and integration (combination) to inclusion that will promote inclusive society development;

- inclusive education consists of: philosophical basis, values and principles of inclusion, success index;

- $\quad$ in inclusive process educational system is adopted to the needs of the disabled child and considers his individual specific developmental features;

- inclusive surrounding provides the development of every participant of inclusive educational process (including children with special educational needs and their peers with normal development);

- inclusive education ideology excludes any discrimination of children, provides equal attitude to every child and special conditions for their special needs.

In order to find optimal ways to renew native inclusive education, it is vital to determine factors that are necessary and specify conditions for inclusive education functioning in Ukraine. 


\section{СПИСОК ВИКОРИСТАНИХ ДЖЕРЕЛ}

1. Колупаєва А. А. Спеціальна освіта в Україні та модернізація освітньої галузі. Особлива дитина: навчання і виховання. 2014. № 3(71). С. 7-13.

2. Байда Л. Ю., Красюкова-Еннс О. В., Азін В. О. [та ін.]. Інвалідність та суспільство: навч.-метод. посіб. / за заг. ред. Л. Ю. Байди, О.В.Красюкової-Еннс. Київ: Канадський центр вивчення інвалідності; ВГСПО «Національна Асамблея інвалідів України», 2012. 216 с.

3. Засенко В., Колупаєва А. Діти з особливими потребами: пріоритетні напрями державної політики України в галузі освіти, соціального захисту й охорони здоров'я. Особлива дитина: навчання $i$ виховання. 2014. № 3(71). С. 20-29.

4. Інклюзивна освіта. Підтримка розмаїття у класі: практ. посіб. / Тім Лорман, Джоан Деппелер, Девід Харві; пер з англ. Київ: СПД-ФО Парашин І. С., 2010. 296 с.

5. Ахметова Д. 3., Нигматов 3. Г., Челнокова Т. А., Юсупова Г. В. [и др.]. Педагогика и психология инклюзивного образования: учебное пособие / под ред. Д. З. Ахметовой. Казань: Изд-во «Познание» Института экономики, управления и права, 2013. 204 с.

6. Саламанская декларация о принципах, политике и практической деятельности в сфере образования лиц с особыми потребностями (принята Всемирной конференцией по образованию лиц с особыми потребностями: доступ и качество, Саламанка, Испания, 7-10 июня 1994 г.). URL: http://www. notabene.ru/down_syndrome/Rus/declarat.html.

7. Мифы об инклюзивных школах. URL: http://kelechek.kg/ru/ professionals/mify_inclusivnyh_shkolah.

8. Инклюзивное сознание. URL: http://www.cablook.com/mixlook/ inklyuzivnoe-soznanie.

\section{REFERENSES}

1. Kolupaieva, A. A. (2014). Sotsialna osvita v Ukraini ta modernizatsiia osvitnioi haluzi. Osoblyva dytyna: navchannia i vykhovannia, 3(71), 7-13 [in Ukrainian].

2. Baida, L. Yu., Krasiukova-Enns, O. V., Azin, O. V. [et al.]. (2012). Invalidnist ta suspilstvo. L. Yu. Baida, O. V. Krasiukova-Enns (Ed.). Kyiv: Kanadskyi tsentr vyvchennia invalidnosti; VHSPO «Natsionalna Asambleia invalidiv Ukrainy» [in Ukrainian].

3. Zasenko, V. \& Kolupaieva, A. (2014). Dity z osoblyvymy potrebamy: priorytetni napriamy derzhavnoi polityky Ukrainy v haluzi osvity, sotsialnoho zahystu y ohorony zdorovia. Osoblyva dytyna: navchannia $i$ vykhovannia, 3(71), 20-29 [in Ukrainian].

4. Lorman, T., Leppler, D., \& Kharvi, D. (2010). Inkliuzyvna osvita. Pidtrymka rozmaittia u klasi. Kyiv: SPD-FO Parashin I. S. [in Ukrainian].

5. Akhmetova, D. Z., Nigmatov, Z. G., Chelnokova, T. A., Yusupova, G. V. [et al.] (2013). Pedagogika i psikhologiya inklyuzivnogo obrazovaniya. D. Z. Akhmetova (Ed.). Kazan: Izd-vo «Poznaniye» Instituta ekonomiki upravleniya i prava [in Russian].

6. Salamankskaya deklaratsiya o printsipakh, politike i prakticheskoy deyatelnosti v sfere obrazovaniya lits $\mathrm{s}$ osobymi potrebnostyami. Vsemirnaya konferentsiya po obrazovaniyu lits s osobymi potribnostyami: dostup $i$ kachestvo, Salamanka, Ispaniya, 7-10 iyunya 1994. URL: http://www.notabene.ru/ down_syndrome/ Rus/declarat.html [in Russian].

7. Mify ob inklyuzivnykh shkolakh. URL: http://kelechek.kg/ru/professionals/mify_inclusivnyh_shkolah [in Russian].

8. Inklyuzivnoye soznaniye [Inclusive consciousness]. URL: http://www.cablook.com/mixlook/inklyuzivnoesoznanie [in Russian]. 